\title{
The consumption of atmospheric methane by soil in a simulated future climate
}

\author{
C. L. Curry \\ Canadian Centre for Climate Modelling and Analysis, Climate Research Division, Environment Canada, Victoria, BC, Canada
}

Received: 15 May 2009 - Published in Biogeosciences Discuss.: 23 June 2009

Revised: 23 September 2009 - Accepted: 26 September 2009 - Published: 2 November 2009

\begin{abstract}
A recently developed model for the consumption of atmospheric methane by soil (Curry, 2007) is used to investigate the global magnitude and distribution of methane uptake in a simulated future climate. In addition to solving the one-dimensional diffusion-reaction equation, the model includes a parameterization of biological $\mathrm{CH}_{4}$ oxidation that is sensitive to soil temperature and moisture content, along with specified reduction factors for land cultivation and wetland fractional coverage. Under the SRES emission scenario A1B, the model projects an $8 \%$ increase in the global annual mean $\mathrm{CH}_{4}$ soil sink by 2100 , over and above the $15 \%$ increase expected from increased $\mathrm{CH}_{4}$ concentration alone. While the largest absolute increases occur in cool temperate and subtropical forest ecosystems, the largest relative increases in consumption $(>40 \%)$ are seen in the boreal forest, tundra and polar desert environments of the high northern latitudes. Methane uptake at mid- to high northern latitudes increases year-round in 2100 , with a $68 \%$ increase over present-day values in June. This increase is primarily due to enhanced soil diffusivity resulting from lower soil moisture produced by increased evaporation and reduced snow cover. At lower latitudes, uptake is enhanced mainly by elevated soil temperatures and/or reduced soil moisture stress, with the dominant influence determined by the local climate.
\end{abstract}

\section{Introduction}

Significant changes in the atmospheric concentrations of long-lived greenhouse gases (GHGs) have accompanied large-scale climate change over the Holocene, including the global warming of recent decades. The influence of climate change on the budgets of GHGs is thus a topic of great in-

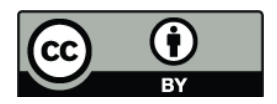

Correspondence to: C. L. Curry (charles.curry@ec.gc.ca) terest, and one that is beginning to be addressed by models of biogeochemical cycles at the global scale (Denman et al., 2007). This paper focuses on the uptake of methane by soils, a process that represents a small but important sink of atmospheric $\mathrm{CH}_{4}$ at the global scale, accounting for approximately $5 \%$ of the total. According to a recent metaanalysis of 318 annual estimates of uptake in wide range of ecosystems (Dutaur and Verchot, 2007), the total annual $\mathrm{CH}_{4}$ uptake ranges from 12-59 $\mathrm{TgCH}_{4} \mathrm{y}^{-1}$, with a narrower estimate of $22 \pm 12 \mathrm{Tg} \mathrm{CH}_{4} \mathrm{y}^{-1}$ if the measurements are stratified by climatic zone, ecosystem, and soil texture.

Uptake of methane in soil occurs via oxidation by specialized aerobic bacteria - methanotrophs - several varieties of which have been identified (Hanson and Hanson, 1996), but the precise physiology of which is still not well understood (Roslev et al., 1997; Knief et al., 2003; Horz et al., 2005). Curry (2007) (hereafter Paper I), presented a physical parameterization of soil $\mathrm{CH}_{4}$ uptake, building on the prior work of Ridgwell et al. (1999) (hereafter R99), in which the diffusion coefficient $D_{\text {soil }}$ and rate of biological oxidation $k$ are the primary variables. Each of these variables is expressed as the product of several factors sensitive to local, timedependent, environmental conditions. Free parameters of the scheme were calibrated using multi-year field measurements, and offline simulations driven with observed reanalysis climate data. The simulated magnitude $\left(28.0 \mathrm{Tg} \mathrm{CH}_{4} \mathrm{y}^{-1}\right.$ in the global and annual mean) and seasonality of $\mathrm{CH}_{4}$ uptake were shown to behave in a physically reasonable manner at several sites with widely varying climate and soil texture.

In the present paper, the same uptake scheme is driven not with reanalysis data, as in Paper I, but rather with the simulated surface climate of an atmospheric general circulation model (GCM) coupled to a slab ocean. This configuration permits time-slice simulations of not just the present day methane uptake pattern, but also its past and future geographical distributions. The subsurface temperature increases associated with atmospheric warming are generally expected to

Published by Copernicus Publications on behalf of the European Geosciences Union. 
enhance methanotrophic activity, except where reduced soil water availability leads to moisture stress. Thus, uncertainty remains regarding the competing influences of increased soil diffusivity and reduced soil water availability over much of the tropics and mid-latitudes in a warmer world. Field studies have shown that consumption may either increase or decrease depending upon moisture availability and clade-specific biology (Schnell and King, 1996; Torn and Harte, 1996; Horz et al., 2005). The present work highlights the importance of future changes in winter snowfall and snow cover in the Northern Hemisphere, through associated changes in soil moisture, diffusivity, and $\mathrm{CH}_{4}$ uptake over the remainder of the year.

This paper estimates the soil sink strength of $\mathrm{CH}_{4}$ in both the present and future climates by driving the model of $\mathrm{Pa}$ per I with surface forcing from an AGCM coupled to a slab ocean. In the following section, I review the parameterization of methane uptake, and in Sect. 3 describe the methodology of the time-slice experiments. Simulated methane uptake in the present climate is then discussed in Sect. 4, while Sect. 5 presents results for simulated future (and preindustrial) climate. In the final section, the results obtained here are compared with those predicted from simpler soil methane consumption schemes, and concluding remarks offered on directions for future progress.

\section{Model overview}

Following Paper I, soil methane uptake at the surface, $J$, is obtained from the first integral of the one-dimensional diffusion-reaction equation, which after some manipulation takes the simple form

$J=g_{0} C_{\mathrm{CH}_{4}} r_{C} r_{W}\left(D_{\text {soil }} k_{0} r_{T} r_{\mathrm{SM}}\right)^{1 / 2}$,

where

$J$ : surface flux (uptake) in $\mathrm{mgCH}_{4} \mathrm{~m}^{-2} \mathrm{~d}^{-1}$; $g_{0}=586.7 \mathrm{mg} \mathrm{CH}_{4} \mathrm{ppmv}^{-1} \mathrm{~s} \mathrm{~d}^{-1} \mathrm{~m}^{-2} \mathrm{~cm}^{-1}$,

conversion factor from mixing ratio to concentration;

$C_{\mathrm{CH}_{4}}$ : $\mathrm{CH}_{4}$ mixing ratio at the surface (ppmv);

$k_{0}$ : first-order oxidation rate constant, $=5.0 \times 10^{-5} \mathrm{~s}^{-1}$, determined from calibration with field data (Paper I);

$r_{C}, r_{W}$ : dimensionless factors $(0-1.0)$ for inhibition of uptake in cultivated soils and wetland areas, respectively (spatial maps of $r_{C}$ and $r_{W}$ are available as online auxiliary material of Paper I);

$r_{T}$ : dimensionless soil temperature factor $(0-4.1)$, increasing for $-10 \leq T_{\text {soil }} \leq 27.5^{\circ} \mathrm{C}$, and decreasing for $T_{\text {soil }}>27.5^{\circ} \mathrm{C}$;

$r_{\mathrm{SM}}$ : dimensionless factor $(0-1.0)$ for inhibition of uptake due to sub-optimal soil moisture. $r_{\mathrm{SM}}$ is assumed to be optimal (=1) for soil water matric potential $\psi<0.2 \mathrm{MPa}$, and decreases smoothly to zero as $\psi$ increases to $100 \mathrm{MPa}$, above which $r_{\mathrm{SM}}=0$. The exact forms of $r_{T}$ and $r_{\mathrm{SM}}$ may be found in Paper I.
The diffusion coefficient of methane in soil, $D_{\text {soil }}$, is given by

$$
\begin{array}{r}
D_{\text {soil }}=0.196\left(1.0+0.0055 T_{\text {soil }}\right) \Phi^{4 / 3}\left(\frac{\Phi_{\text {air }}}{\Phi}\right)^{1.5+3 / b} \\
\mathrm{~cm}^{2} \mathrm{~s}^{-1}
\end{array}
$$

where

$\Phi$ : total porosity $\left(\mathrm{cm}^{3} \mathrm{~cm}^{-3}\right)$,

$\Phi_{\text {air }}$ : air-filled porosity $\left(\mathrm{cm}^{3} \mathrm{~cm}^{-3}\right)=\Phi-\theta$,

$\theta=\theta_{w}+\theta_{i}$,

$\theta_{w}$ : fractional water content,

$\theta_{i}$ : fractional ice content,

$b=15.9 f_{\text {clay }}+2.91, f_{\text {clay }}$ : fraction of clay.

All quantities are two-dimensional, depth-averaged fields over the top $10 \mathrm{~cm}$ soil layer. Note that both $D_{\text {soil }}$ and $r_{\mathrm{SM}}$ depend on soil moisture, but in roughly opposite ways. The dependence of $J$ on the square root of $D_{\text {soil }}$ and $k \equiv k_{0} r_{T} r_{\mathrm{SM}}$, as opposed to the linear dependence assumed by R99 and others, has recently received support from field and laboratory studies (von Fischer et al., 2009).

\section{Methodology and simulations}

The methane consumption algorithm was incorporated into the Canadian Centre for Climate Modelling and Analysis (CCCma) third generation atmospheric GCM (AGCM3), an improved version of the model described in McFarlane et al. (1992). AGCM3 represents the horizontal structure of the main prognostic variables using a spectral representation, with T63 truncation in the present application and a corresponding gaussian physics grid of $2.8^{\circ} \times 2.8^{\circ}$. There are 31 sigma-hybrid vertical levels between $995 \mathrm{mb}$ and $1 \mathrm{mb}$. Further description of this model version may be found in Scinocca et al. (2009).

The $\mathrm{CH}_{4}$ uptake subroutine was implemented in CLASS (Canadian LAnd Surface Scheme) v2.7, the land scheme currently used in AGCM3 (Verseghy, 1991, 1996), which runs at a 15-min time step. The uptake calculation is performed only in the top $(0-10 \mathrm{~cm})$ soil layer of CLASS, since measured oxidation rates are usually small below this depth. Within this top soil layer, $D_{\text {soil }}$ and $k$ are assumed to be vertically homogeneous, although they do vary in the horizontal (i.e., from one grid cell to the next).

To enable the simulation of future climate, AGCM3 was coupled to a $50 \mathrm{~m}$-thick slab ocean model including a prognostic sea ice component. Specified surface flux ("q-flux") adjustments, derived from a prior model run in which SSTs are restored toward climatological values, were added to the slab model's temperature tendency equation at each time step (in both present and future time-slice simulations) to give a more realistic distribution of SSTs. This strategy suits the present application since it allows an evaluation of the $\mathrm{CH}_{4}$ sink strength at all land points in a significantly altered climate at a reasonable computational cost. 
Three time-slice simulations were performed with this model configuration (see Table 3 for GHG concentrations used in each experiment): (1) a 40-year equilibrium run using present-day (ca. 1994) GHG concentrations; (2) a 40-year equilibrium run using GHG concentrations from the SRES A1B (ISAM reference) scenario at 2100, with CFC concentrations from the WMO98 Scenario A1; and (3) a 40-year equilibrium run using preindustrial (ca. 1850) GHG concentrations. The simulations were started from the end states of previously archived runs at CCCma for $1 \times \mathrm{CO}_{2}$ $\left(\left[\mathrm{CO}_{2}\right]=348 \mathrm{ppmv}\right)$ and $2 \times \mathrm{CO}_{2}\left(\left[\mathrm{CO}_{2}\right]=696 \mathrm{ppmv}\right)$ equilibrium climates. All other features of the model, in particular, the land cover including the cultivated fraction in each grid cell, were held fixed at their present-day distributions. Soil $\mathrm{CH}_{4}$ uptake is assumed to be zero over areas of permanent water, ice, and desert.

After an adjustment period of 5-10 years after the start of each simulation (caused by the slight change in GHG concentrations), the top soil layer temperature equilibriates to the new climate. Analysis was conducted on averages of the last 20 years of each simulation.

\section{Methane uptake in the simulated present-day climate}

The characteristics of methane uptake in the present-day, model-simulated climate were examined first. A spatial map of the annual mean uptake is shown in Fig. 1a. As in Paper I, the regions of largest uptake are in South America, subSaharan and far southern Africa, and south-central Australia. Some of the highest uptake cells border large deserts, where spatial variability is high due to the low soil moisture threshold effect of $r_{\mathrm{SM}}$ (Sect. 4.2 of Paper I).

Figure 1a may be compared with the results of Paper I (Fig. 6a, on the same colour scale), in which CLASS was forced with reanalysis data from the 21-year (1979-1999) Global Land Surface Dataset (GOLD) of Dirmeyer and Tan (2001), hereafter referred to as the "GOLD" run. The difference between the two simulations, after averaging the model map onto the coarser resolution of the GOLD run, is shown in Fig. 1b. The spatial pattern of uptake is quite similar in the two cases, although the global total of $24.8 \mathrm{Tg} \mathrm{CH}_{4} \mathrm{y}^{-1}$ derived from the GCM climate is $11 \%$ smaller than the 28.0 $\mathrm{Tg} \mathrm{CH}_{4} \mathrm{y}^{-1}$ found using the GOLD forcing. The most notable regional difference is the generally larger uptake over South America in the GOLD run, although differences of comparable size and the same sign are also seen in eastern Russia, southern China/Himalayas and western North America. Conversely, the coupled model simulates notably larger uptake than in the GOLD run over sub-Saharan Africa, Mongolia, western Amazonia, and much of Australia. In relative terms, the discrepancy is largest at northern high latitudes, where at some grid points the uptake is over $80 \%$ larger under the reanalysis forcing; however, $\mathrm{CH}_{4}$ consumption is typically quite low in these regions to begin with.

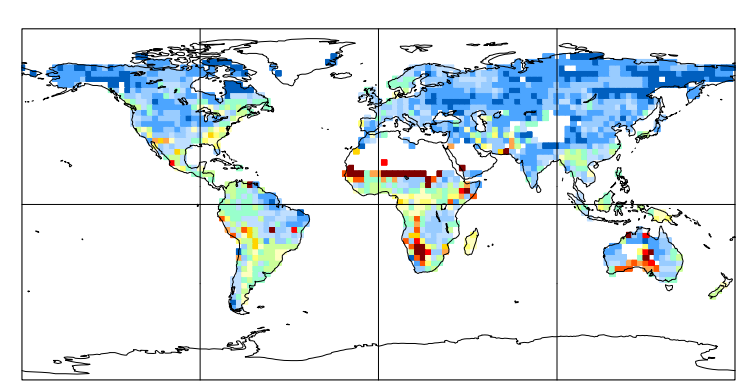

(a)
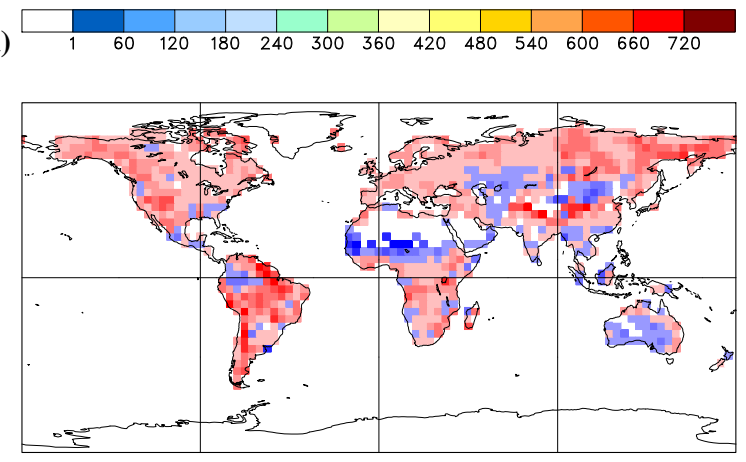

(b)

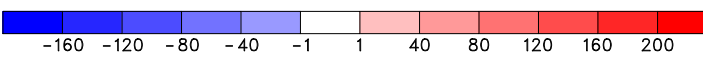

Fig. 1. (a) Global distribution of 20-year annual mean $\mathrm{CH}_{4}$ uptake. Units are $\mathrm{mg} \mathrm{CH}_{4} \mathrm{~m}^{-2} \mathrm{y}^{-1}$. The globally integrated uptake is $24.8 \mathrm{Tg} \mathrm{CH}_{4} \mathrm{y}^{-1}$. (b) Difference of 21-year annual mean $\mathrm{CH}_{4}$ uptake with GOLD forcing minus 20 -year annual mean $\mathrm{CH}_{4}$ uptake from the model.

There are two principal causes of the positive anomalies seen in Fig. 1b. First, as shown in Fig. 2a, the top soil layer temperature in the GOLD run is generally larger (by $+2.5^{\circ} \mathrm{C}$, in the global mean) than in the coupled model simulation. The largest differences are seen in western North and South America, sub-Saharan Africa, and the western Himalayas. Comparison of the annual mean GOLD 2-m surface air temperature with ERA-40 (the European Centre for Medium-Range Weather Forecasts second extended reanalysis product) data (not shown) over the same period (19791999) reveals a similarly distributed pattern of temperature bias in the GOLD reanalysis. The discrepancy is largest in arid and high elevation $(z 2000 \mathrm{~m})$ regions, where the temperature difference is of magnitude $4-20^{\circ} \mathrm{C}$. Particularly notable is a $8-12^{\circ} \mathrm{C}$ bias over the western two-thirds of the Sahara; although most of the latter region is masked out of the uptake calculation (see auxiliary Fig. 1, Paper I), grid cells along the southern boundary are included. North of $\sim 45^{\circ} \mathrm{N}$, the GOLD and ERA-40 surface air temperatures are in better agreement, with the differences confined to the range -4 to $+2^{\circ} \mathrm{C}$. Since much of Asia and all of Australia have a negative temperature bias in GOLD, the global (land-only) average surface air temperature difference between the two datasets (GOLD minus ERA-40) is only $+0.87^{\circ} \mathrm{C}$. 


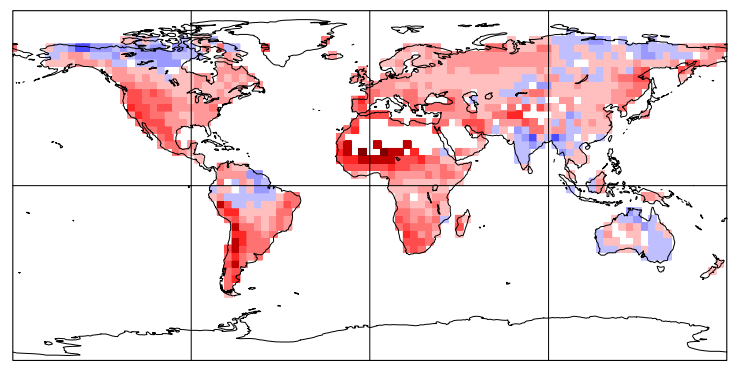

(a)
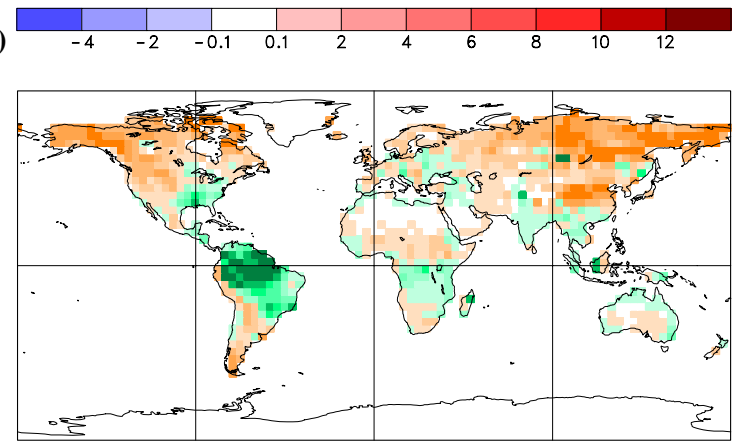

(b)

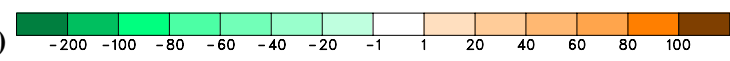

Fig. 2. Difference (GOLD minus coupled model) of 20-year annual mean: (a) top soil layer temperature, $T_{\text {soil }}$, in degrees; (b) diffusivity, $D_{\text {soil }}$, in percent.

One sees less of a difference between the ERA- 40 and coupled model surface air temperatures (not shown), with the anomalies confined to the range $\pm 2^{\circ} \mathrm{C}$ over most land areas, except in western North America and Asia north of $\sim 45^{\circ} \mathrm{N}$, where the ERA- 40 values are systematically larger by $2-6^{\circ} \mathrm{C}$ at most locations. The global mean difference (ERA-40 minus model, land only) is $+1.2^{\circ} \mathrm{C}$. While the sum of these global mean differences (ERA-40 minus model plus GOLD minus ERA-40) is still smaller than the $T_{\text {soil }}$ difference between the GOLD and coupled runs $\left(+2.5^{\circ} \mathrm{C}\right)$, there is a good correspondence between the air and soil temperature difference patterns over all regions south of $\sim 30^{\circ} \mathrm{N}$. The larger magnitude of the soil temperature difference is consistent with the higher specific heat of soil, especially when moist, compared to air.

From the above results I infer the following. First, due to a high surface temperature bias (GOLD minus ERA-40) in the data used to drive the offline $\mathrm{CH}_{4}$ uptake scheme, it is likely that $\mathrm{CH}_{4}$ uptake in the extratropics was overestimated in Paper I. Second, due to a low surface temperature bias (model minus ERA-40) in the northern extratropical land areas compared to observations, it is likely that $\mathrm{CH}_{4}$ uptake in these regions is underestimated by the version of the coupled GCM used in this study. Thus, treating these biases as roughly equal but opposite in sign, I adopt a range of 24.8-28.0 $\mathrm{Tg} \mathrm{CH}_{4} \mathrm{y}^{-1}$ as a reasonable annual mean estimate for the present-day globally integrated $\mathrm{CH}_{4}$ con- sumption. Including the uncertainty in the base oxidation rate constant $k_{0}$ as outlined in Paper I, this translates into a $(2 \sigma)$ range of $J=8-47 \mathrm{Tg} \mathrm{CH}_{4} \mathrm{y}^{-1}$. This range of estimates compares well with the observational constraints of Dutaur and Verchot (2007) mentioned in the Introduction - i.e., 12$59 \mathrm{Tg} \mathrm{CH}_{4} \mathrm{y}^{-1}$, with a best estimate of $22 \pm 12 \mathrm{Tg} \mathrm{CH}_{4} \mathrm{y}^{-1}$. While the level of disagreement between the GOLD and ERA-40 air temperatures is disconcerting, and suggests replacing the former by the latter in future offline runs, it does not impact the goal of the present study: namely, to simulate the difference between present and future climate (including air and soil temperatures), and $\mathrm{CH}_{4}$ uptake derived from the latter, using the coupled model.

The temperature biases just described translate into differences in the methane uptake pattern seen in Fig. $1 \mathrm{~b}$ in the following manner. While the larger $T_{\text {soil }}$ of the GOLD run enhances uptake in most of North and South America and much of Asia, it reduces $J$ in sub-Saharan Africa. There, temperatures in the GOLD run frequently exceed $27.5^{\circ} \mathrm{C}$, where $r_{T}$ attains its maximum value, leading to extensive regions of negative $r_{T}$ change (not shown). Central and southern Australia is another large area over which $r_{T}$ decreases, but here a coincident decrease in $T_{\text {soil }}$ is seen (Fig. 2a). More generally, it is the more modest elevated soil temperatures ( 0 to $+4^{\circ} \mathrm{C}$ ) over the central continental regions in the GOLD run that are responsible for the bulk of the global methane uptake discrepancy due to differing soil temperatures.

A second contribution to the discrepancy in $J$ comes from differences in the diffusion coefficient, $D_{\text {soil }}$, as shown in Fig. 2b. Since $D_{\text {soil }}$ has only a weak temperature dependence (Eq. 2), these differences are attributable to significantly different air-filled porosity, and thus fractional water content, $\theta$, in the two simulations. The spatial pattern of the $D_{\text {soil }}$ difference clearly mirrors that of $J$ at high northern latitudes, where differences in $J$ between the GOLD and coupled runs are largest in relative (but not absolute) terms. By contrast, $T_{\text {soil }}$ is biased negative in the GOLD reanalysis over more than half the land area at these latitudes, implying that the larger uptake in the offline calculation is not temperaturerelated. In these regions, the magnitude of the $D_{\text {soil }}$ difference indicates that $\theta$ is approximately $50 \%$ smaller in the GOLD run.

The $D_{\text {soil }}$ differences south of $\sim 30^{\circ} \mathrm{N}$ are well-correlated with the annual mean precipitation difference between the two runs (not shown). Over much of South America, equatorial Africa, and Australia, the soil is drier in the model simulation than in the GOLD run, leading to a larger model $D_{\text {soil }}$. The model has slightly more precipitation than the reanalysis over most of the northern extratropics, and also less evaporation, consistent with the lower model $D_{\text {soil }}$ there. The large relative differences seen in $D_{\text {soil }}$ are, however, mostly due to differences in snow cover between the model and reanalysis data. Due to the low intrinsic diffusivities at high latitudes, $\sim 10^{-5}$ to a few times $10^{-3} \mathrm{~cm}^{2} \mathrm{~s}^{-1}$, even a small change in the surface water balance has a marked impact on diffusivity 
and, therefore, on methane uptake (see ff. Sect. 5.1.4). Comparison of Figs. $1 \mathrm{~b}$ and $2 \mathrm{~b}$ suggests that despite larger diffusivities in the coupled model in the tropics (where over twothirds of the global annual uptake occurs in the GOLD run; Fig. 6a of Paper I), the discrepancy in $\mathrm{CH}_{4}$ uptake is dominated by the soil temperature bias, since the mean $J$ over the tropics remains larger in the GOLD-forced simulation.

Finally, although model validation was carried out in Paper I, some differences between the modelled and observed range of soil methane uptake over different biomes are worth noting. Table 2 summarizes the distribution of uptake over ecosystem type, as represented in the aggregated Holdridge life zone classification (AHLZ; Paper I). Unfortunately, this classification differs from the Leemans (1990) biozone scheme used by Dutaur and Verchot (2007), the most complete summary of observations to date, so direct comparisons are not possible. However, one of the most evident distinctions seen in the data is that between uptake in forest versus non-forest soils. The ratio of forest to nonforest soil $\mathrm{CH}_{4}$ uptake per unit area in the model is 1.6, compared to 2.4 in the observations, while the corresponding area-weighted ratios are 2.3 (model) and 1.7 (observations). Differing coverage by forests (57\% of the total land area in AHLZ versus $39 \%$ in the Leemans scheme) may explain much of the difference between the last two ratios. However, it does seem likely that the model underestimates this ratio, in areal terms, compared to observations. Further, the modelled areal uptake in tropical forests exceeds that in temperate forests, the reverse of what is found for observational mean values. However, the variance of observed uptake in temperate forests $(N=92)$ is a factor of 6.5 larger than in tropical forests $(N=62)$, implying that mean values may poorly characterize the true distribution.

\section{Methane uptake in a simulated future climate}

\subsection{Annual mean results}

In the simulated future climate, $\mathrm{CH}_{4}$ consumption is expected to increase linearly with surface concentration $C_{\mathrm{CH}_{4}}$, according to Eq. (1). Thus, in the absence of other changes, the globally uniform increase of $C_{\mathrm{CH}_{4}}$ from $1.720 \mathrm{ppmv}$ to $1.974 \mathrm{ppmv}$ under the SRES A1B concentration scenario $(0.254 \mathrm{ppmv}$ or $15 \%)$ would lead to an increase in global uptake of the same magnitude, i.e. an increase of $3.72 \mathrm{Tg} \mathrm{CH}_{4} \mathrm{y}^{-1}$ over the present day simulated value of 24.8 $\mathrm{Tg} \mathrm{CH}_{4} \mathrm{y}^{-1}$. In fact, the globally integrated uptake in the future run is $30.4 \mathrm{TgCH}_{4} \mathrm{y}^{-1}, 23 \%$ higher than the present day value. Since this study focuses on the effects of climate change on the character of $\mathrm{CH}_{4}$ uptake independent of the increase due to elevated concentration alone, the effect of the latter is removed in the analysis that follows, except when citing absolute uptake values in the future climate.
A spatial map of the 20-year annual mean difference in uptake between 2100 and present-day, with the concentration effect removed, is shown in Fig. 3. The relative change in uptake, $\Delta J / J=[J(2100) / J(1994)-1] \times 100 \%$ (Fig. 3b), is less than $\pm 20 \%$ over most of the Southern Hemisphere (SH) land areas and the Northern Hemisphere $(\mathrm{NH})$ tropics $(0-$ $30^{\circ} \mathrm{N}$ ), with the exception of the east coast of S. America from $15^{\circ} \mathrm{S}$ to $15^{\circ} \mathrm{N}, \mathrm{N}$. Africa, and western Mexico, where decreases of $20-50 \%$ are seen. With the exception of two adjacent grid cells in Somalia and Kenya (see ff. Sect. 5.1.3), large relative increases in $J(>40 \%)$ are seen only in the $\mathrm{NH}$ extratropics, and exceed $+120 \%$ in many areas, mostly in the Arctic. The global mean change in $J$, with the concentration effect removed, is $+7.5 \%$.

Changes in the annual mean $J$ are due to both increased surface heating in the future climate, which affects both sub-surface temperature and soil moisture (through evaporation), and to differences in future precipitation patterns and amount, which affect $D_{\text {soil }}$ (recall that the model land cover in 2100 remains unchanged from present-day). Figure $4 a-c$ show the corresponding difference patterns for $r_{T}, r_{\mathrm{SM}}$ and $D_{\text {soil }}$. While certain similarities in patterns can be detected between Figs. 3 and 4, interannual variability of many of the fields can make attribution difficult. The contribution of the relative changes in $\Delta D_{\text {soil }}, \Delta r_{T}$, and $\Delta r_{\mathrm{SM}}$ to $\Delta J$ at each grid cell can be derived directly from Eq. (1):

$$
\begin{aligned}
\frac{\Delta J}{J} & =\left(\frac{D_{\text {Soil }}^{*}}{D_{\text {soil }}} \frac{r_{T}^{*}}{r_{T}} \frac{r_{\mathrm{SM}}^{*}}{r_{\mathrm{SM}}}\right)^{1 / 2}-1 \\
& \approx \frac{1}{2}\left(\frac{\Delta D_{\text {soil }}}{D_{\text {soil }}}+\frac{\Delta r_{T}}{r_{T}}+\frac{\Delta r_{\mathrm{SM}}}{r_{\mathrm{SM}}}\right),
\end{aligned}
$$

where the superscript "**" indicates the value in 2100 (i.e., $D_{\text {soil }}^{*}=D_{\text {soil }}+\Delta D_{\text {soil }}, \ldots$, etc.) and the second relation holds if all the $\Delta$ 's are small compared to present day (a good approximation over $40^{\circ} \mathrm{S}-40^{\circ} \mathrm{N}$ ). Hence, each of these agents contributes to $\Delta J / J$ in the same proportion; it remains only to assess the relative changes in the fields themselves over the region of interest. The zonally averaged results of this comparison are shown in Fig. 5. Note that due to the larger magnitude of the changes at high northern latitudes, a different vertical scale has been used for $40-75^{\circ} \mathrm{N}$.

In order to better understand the space-time correlation between $\Delta J / J$ and each of the three predictor fields, as well as amongst the predictor fields themselves, a regression analysis was also performed using the individual monthly mean output from which the 20-year mean fields were constructed. The Pearson (linear) correlation coefficient $r$ was calculated from 240 individual monthly grids of each relative difference field (i.e., $\Delta J / J$ versus $\Delta D_{\text {soil }} / D_{\text {soil }}, \Delta J / J$ versus $\Delta r_{T} / r_{T}, \ldots$, etc.), over separate bands of latitude as presented in Table 1. The magnitude of $r$ reflects the degree to which the change in a quantity is correlated $(r>0)$ or anti-correlated $(r<0)$ with another quantity. Figure 5 and 


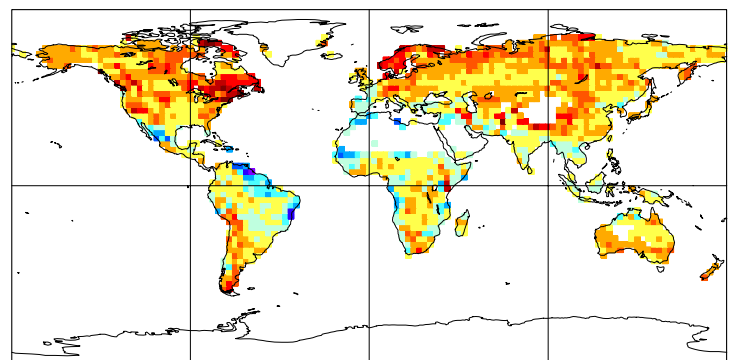

(a)
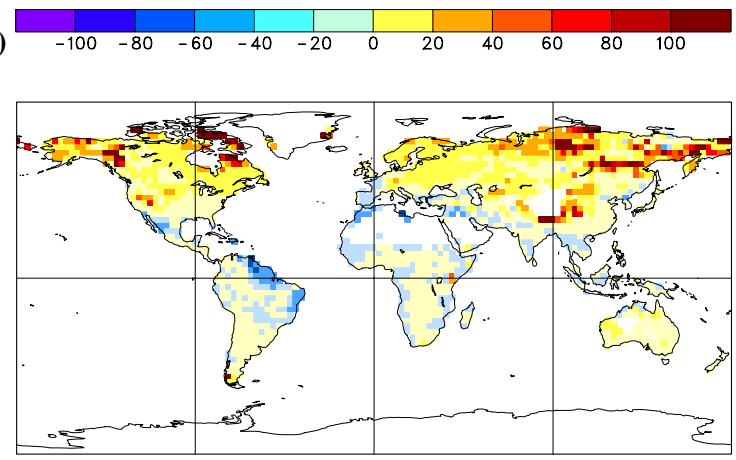

(b)

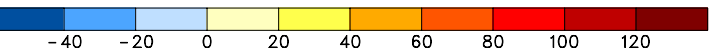

Fig. 3. Difference (2100 minus present-day) of 20 -year annual mean $\mathrm{CH}_{4}$ uptake, with the effect of the uniform concentration increase removed: (a) absolute values in $\mathrm{mg} \mathrm{CH}_{4} \mathrm{~m}^{-2} \mathrm{y}^{-1}$; (b) expressed as a percent.

Table 1 should be consulted as the role of each of these contributors is considered in turn.

\subsubsection{Soil temperature}

The mean increase in $T_{\text {soil }}$ from the present to 2100 is $3.5 \pm 1.4^{\circ} \mathrm{C}$, and the geographical pattern (not shown) resembles previously published results, particularly with respect to the marked warming asymmetry at northern high latitudes (Hegerl et al., 2007). This $\Delta T_{\text {soil }}$ leads to changes in the factor $r_{T}$ that generally resemble $\Delta T_{\text {soil }}$, except in the tropics where $\Delta r_{T}<0$, as shown in Fig. 4a. There, temperatures frequently exceed $27.5^{\circ} \mathrm{C}$, above which $r_{T}$ starts to decrease, leading to extensive regions of negative $\Delta r_{T}$ in South America, sub-Saharan Africa, and northern Australia. The contribution of $\Delta r_{T} / r_{T}$ to $\Delta J / J$ ranks second to that of diffusivity at most latitudes, although it exceeds $\Delta D_{\text {soil }} / D_{\text {soil }}$ between 20-40 ${ }^{\circ} \mathrm{S}$ and $35-55^{\circ} \mathrm{N}$ (Fig. 5 and Table 1). In general, $\Delta r_{T} / r_{T}$ and $\Delta D_{\text {soil }} / D_{\text {soil }}$ are weakly correlated, with the closest correspondence in the mid-latitudes, where increases in $T_{\text {soil }}$ lead to soil drying and higher air-filled porosity and diffusivity. $\Delta r_{T} / r_{T}$ and $\Delta r_{\mathrm{SM}} / r_{\mathrm{SM}}$ are anti-correlated over southern mid-latitudes, indicating increased moisture stress under warming, but are only weakly correlated elsewhere, since $r_{\mathrm{SM}}$ depends more directly upon soil water content, and thus diffusivity, than $T_{\text {soil }}$ (see Sect. 5.1.3).

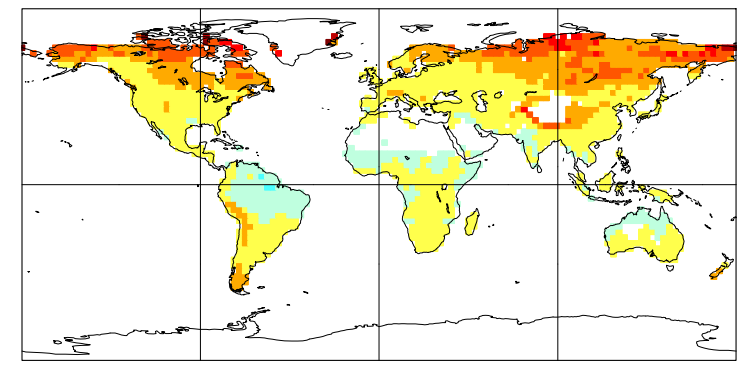

(a)
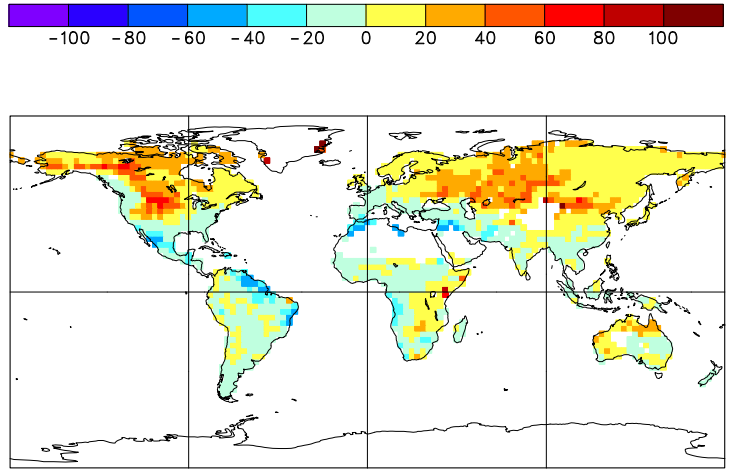

(b)
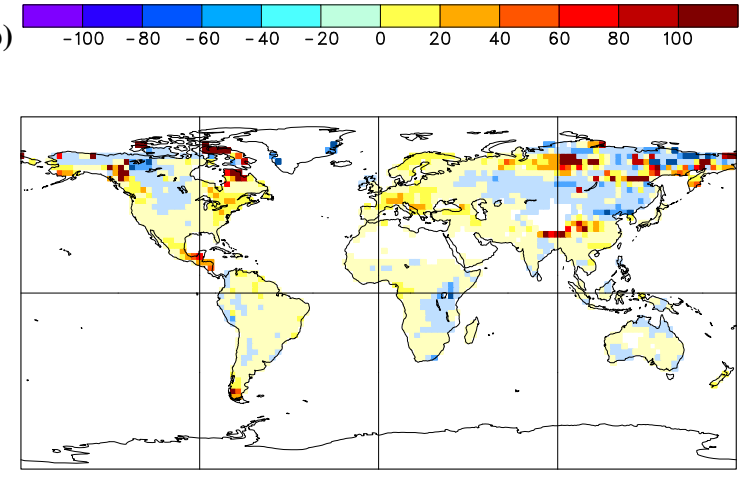

(c)
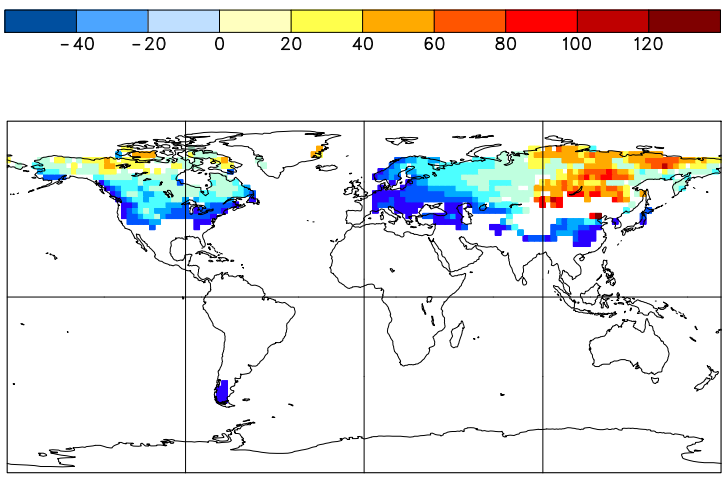

(d)

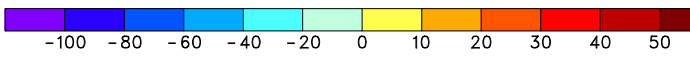

Fig. 4. Relative change (2100 minus present-day, in percent) of 20year annual mean fields: (a) $r_{T}$; (b) $r_{\mathrm{SM}}$; (c) $D_{\text {soil }}$; (d) snow cover. 
Table 1. Linear (Pearson) correlation coefficients of indicated monthly mean fields.

\begin{tabular}{|c|c|c|c|c|}
\hline & & $\Delta D_{\text {soil }}$ & $\Delta r_{T}$ & $\Delta r_{\mathrm{SM}}$ \\
\hline \multicolumn{5}{|l|}{$60-90^{\circ} \mathrm{N}$} \\
\hline & $\Delta J$ & 0.686 & 0.392 & -0.076 \\
\hline & $\Delta D_{\text {soil }}$ & & 0.152 & -0.332 \\
\hline & $\Delta r_{T}$ & & & 0.127 \\
\hline \multicolumn{5}{|l|}{$30-60^{\circ} \mathrm{N}$} \\
\hline & $\Delta J$ & 0.144 & 0.161 & 0.175 \\
\hline & $\Delta D_{\text {soil }}$ & & 0.205 & -0.646 \\
\hline & $\Delta r_{T}$ & & & -0.107 \\
\hline \multicolumn{5}{|l|}{$0-30^{\circ} \mathrm{N}$} \\
\hline & $\Delta J$ & -0.122 & 0.215 & 0.355 \\
\hline & $\Delta D_{\text {soil }}$ & & -0.146 & -0.911 \\
\hline & $\Delta r_{T}$ & & & 0.142 \\
\hline \multicolumn{5}{|l|}{$30-0^{\circ} \mathrm{S}$} \\
\hline & $\Delta J$ & -0.207 & 0.207 & 0.408 \\
\hline & $\Delta D_{\text {soil }}$ & & -0.099 & -0.932 \\
\hline & $\Delta r_{T}$ & & & 0.094 \\
\hline \multicolumn{5}{|l|}{$60-30^{\circ} \mathrm{S}$} \\
\hline & $\Delta J$ & 0.042 & -0.028 & 0.226 \\
\hline & $\Delta D_{\text {soil }}$ & & 0.240 & -0.916 \\
\hline & $\Delta r_{T}$ & & & -0.293 \\
\hline \multicolumn{5}{|l|}{ Global } \\
\hline & $\Delta J$ & 0.514 & 0.201 & 0.250 \\
\hline & $\Delta D_{\text {soil }}$ & & 0.043 & -0.755 \\
\hline & $\Delta r_{T}$ & & & 0.020 \\
\hline
\end{tabular}

\subsubsection{Precipitation, evaporation, and soil moisture}

According to the Clausius-Clapeyron relation, higher specific humidity in a warmer atmosphere should lead to increased poleward moisture transport and hence increased precipitation at high latitudes. This increase is seen in our simulations nearly everywhere north of $45^{\circ} \mathrm{C}$ in the future climate, with a more mixed difference pattern in the tropics and subtropics (not shown). The global, land-only, precipitation change in future is $\Delta P=+56 \mathrm{~mm} \mathrm{y}^{-1}(+6 \%)$. Increases in evaporation are seen on every continent, and while these are generally of smaller magnitude than the precipitation changes $\left(\Delta E=+39 \mathrm{~mm} \mathrm{y}^{-1}\right)-$ i.e., $\Delta(P-E)$ is positive - globally $\Delta E / E$ exceeds $\Delta P / P$ by $\sim 1 \%$. In the global mean, the net effect of these atmospheric moisture changes on the upper soil layer moisture $\theta_{w}$ is not significant; i.e., $\Delta \theta_{w}=-3.6 \times 10^{-3}$. However, the regional variation of $\Delta \theta_{w}$ (roughly complementary to that of $D_{\text {soil }}$; see Fig. 4c) has an important influence on two of the principal determinants of the $\mathrm{CH}_{4}$ soil uptake: namely, the soil moisture stress factor $r_{\mathrm{SM}}$ and the diffusivity $D_{\text {soil }}$.
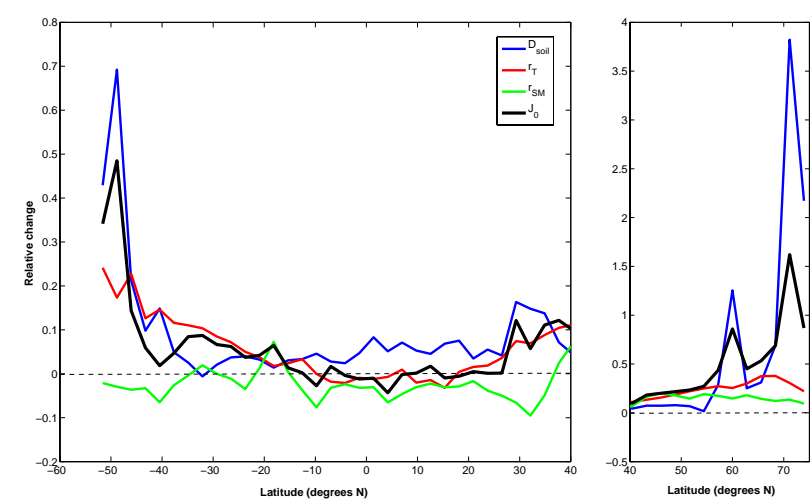

Fig. 5. Relative change ( 2100 minus present day) of the indicated 20 -year annual mean fields as a function of latitude. Note that due to the larger magnitude of the changes at high northern latitudes, a different vertical scale is used for $40-75^{\circ} \mathrm{N}$.

\subsubsection{Soil moisture stress}

As shown in Fig. 4 b, $r_{\mathrm{SM}}$ increases nearly everywhere north of $45^{\circ} \mathrm{C}$ in the future climate, except in western Europe (where $P-E$ decreases) and western North America (where $P-E$ increases but runoff to the Pacific Ocean is large). The strongest increases are seen over western Asia and the Great Plains of North America, where present day values of $r_{\mathrm{SM}}$ are well below the global mean. Even a modest increase in soil water content over these areas, as seen in Fig. 4b, can lead to a large relative increase in $r_{\mathrm{SM}}$. Indeed, even in regions where the annual mean soil moisture $\theta_{w}$ decreases in future (such as eastern Europe), $r_{\mathrm{SM}}$ can still increase, as long as $\theta_{w}$ increases in the drier months. This is due to the insensitivity of $r_{\mathrm{SM}}$ to $\theta_{w}$ at large $\theta_{w}$ (Eqs. 8 and 9 in Paper I). In this regime, methane uptake is limited by diffusivity, not $r_{\mathrm{SM}}$, and hence the pattern of $r_{\mathrm{SM}}$ more closely resembles that of $P$, not $\theta_{w}$. Thus, despite the strong and widespread increase of $r_{\mathrm{SM}}$ seen in Fig. 4b, the correlation of $r_{\mathrm{SM}}$ with $J$ is generally weak at northern latitudes. This is due to similarly distributed decreases in $D_{\text {soil }}$ (see below), which limit the overall $J$ increase.

Substantial decreases in $r_{\mathrm{SM}}$ are seen south of $\sim 30^{\circ} \mathrm{N}$, with the largest regional decreases $(20-60 \%)$ seen on the east coast of S. America from $15^{\circ} \mathrm{S}$ to $15^{\circ} \mathrm{N}, \mathrm{N}$. Africa and the Middle East, and western Mexico. These are also areas of strongly decreased methane consumption in future (Fig. 3). Positive correlations of $\Delta r_{\mathrm{SM}}$ with $\Delta J$ are seen at latitudes south of $\sim 30^{\circ} \mathrm{N}$ (Table 1), suggesting that decreased water availability is largely responsible for the reduced or weakly enhanced methane uptake in these regions. Two-dimensional correlation maps (not shown) show that only in Amazonia is the influence of temperature $\left(\Delta r_{T}<0\right)$ comparable to that of $r_{\mathrm{SM}}$ in this respect. Notable exceptions to the decreasing $r_{\mathrm{SM}}$ trend south of $\sim 30^{\circ} \mathrm{N}$ are equatorial eastern Africa and northern Australia, where large increases in annual precipitation lead to a partial alleviation of moisture stress in those 
regions (Fig. 4b). In locations where $r_{\mathrm{SM}}$ is particularly low in the present climate (e.g., at the two adjacent grid cells in Somalia and Kenya previously noted in Sect. 5.1), large relative increases in $r_{\mathrm{SM}}$ and, consequently, $J$ occur.

Generally speaking, decreasing precipitation in future in the tropics leads to decreased soil water, which lowers $r_{\mathrm{SM}}$. Where decreases in $r_{\mathrm{SM}}$ are largest, methane uptake decreases. However, the total area of regions with $\Delta r_{\mathrm{SM}}<0$ is larger than that with $\Delta J<0$, indicating that changes in temperature and diffusivity can still lead to an increase in future uptake. Table 1 shows that $\Delta r_{\mathrm{SM}}$ and $\Delta D_{\text {soil }}$ are strongly anti-correlated at nearly all latitudes, with the tightest relation holding between $60^{\circ} \mathrm{S}$ and $30^{\circ} \mathrm{N}$. This reflects the dominant dependence of both factors on $\theta_{w}$. As seen in Fig. 5, soil temperature and diffusivity are the dominant controls on methane uptake at high latitudes, and even substantial changes in $r_{\mathrm{SM}}$ have little impact.

\subsubsection{Diffusivity and snow cover}

The pattern of future diffusivity change, shown in Fig. 4c, is the complement of the change in soil moisture, $\theta_{w}$, mentioned above. $D_{\text {soil }}$ increases more or less uniformly across Europe, the United States, and South America, with more heterogeneous changes seen elsewhere. The global and annual mean change in $D_{\text {soil }}$ is $+5.1 \%$, despite the fact that $\Delta(P-E)>0$, implying that soil moisture vertical transport and storage play an important role. In particular, the positive sign of $\Delta D_{\text {soil }}$ cannot be taken as simply an indication of increased evaporation in a warmer climate, independent of other factors. Figure 5 and Table 1 show that $\Delta D_{\text {soil }}$ and $\Delta J$ are anti-correlated in the equatorial band, coincident with positively correlated $\Delta r_{\mathrm{SM}}$, due to the anomalous drying of the soil in these regions (and, in the case of the Amazon, a significant decrease in $r_{T}$ ). The strongest positive correlations of $\Delta D_{\text {soil }}$ with $\Delta J$ are seen north of $60^{\circ} \mathrm{N}(r=0.69)$.

It is apparent from Fig. $4 \mathrm{c}$ that $\Delta D_{\text {soil }}$ is highly spatially variable in east Asia, where the relative change in $J$ is also the largest anywhere on the globe (Fig. 3b). This characteristic is likely linked to changes in future snow cover at those locations. As Fig. $4 d$ shows, the snow cover difference pattern over east Asia (and far northern Canada, another region with strongly-varying $D_{\text {soil }}$ ) is also highly spatially variable with alternating sign, in contrast to other NH locations. The marked east-west asymmetry in snow cover change over northern Asia is the result of a similarly asymmetric pattern of snowfall change. Positive $D_{\text {soil }}$ changes are associated with areas of decreasing snow cover, albeit of smaller magnitude. However, due to the aforementioned low soil diffusivities at high latitudes (Sect. 4), even small changes in surface water balance can strongly affect diffusivity. Moreover, soil porosities in east Asia are $\sim 15-25 \%$ smaller than in west Asia and Europe (Zobler, 1986), meaning that increased soil water from spring snow melt in east Asia more strongly moderates diffusivity and uptake there. In Europe and western Asia, less snow above ground in winter leads to decreased soil moisture in $\mathrm{NH}$ summer, and thus to higher annual mean $D_{\text {soil }}$.

Therefore, while the presumption of increasing diffusivity under surface warming holds for global and even zonal means, it fails over large geographic areas where low porosity soils underlie a more varied hydrological regime. Further, while areas of strong increase in $D_{\text {soil }}$ lead to similarly large increases in $J$, beneficial changes in $r_{T}$ and $r_{\mathrm{SM}}$ lead to positive $\Delta J$ even where $D_{\text {soil }}$ decreases. Thus the pattern of $\Delta J$ (Fig. 3a) is considerably smoother than that of $\Delta D_{\text {soil }}$ (Fig. 4).

To sum up the annual mean results, Fig. 4a, b and c taken together present a clear picture of how the relative change in each of the key factors contributes to the change in methane flux. The zonal means of these fields, shown in Fig. 5, allow a more direct comparison of the relative strengths of these factors at different latitude, while Table 1 gives the corresponding correlation coefficients. Finally, note that due to spatial and temporal averaging, large regional correlations and anti-correlations can sometimes sum to near-zero mean values. This explains why, e.g., $\Delta J$ and $\Delta D_{\text {soil }}$ are essentially uncorrelated in the zonally averaged $30-60^{\circ} \mathrm{S}$ latitude band (Table 1), despite the large relative contribution of $\Delta D_{\text {soil }}$ to $\Delta J$ evident in Fig. 5.

\subsection{Seasonal differences}

I now investigate how future methane uptake changes depend on latitude and season. Figure 6 is a Hovmueller diagram showing the seasonality of various zonally averaged fields, each normalized by the fractional land area at each latitude. The seasonal cycle of methane uptake in the present day climate is shown in Fig. 6a. The continuous band of high uptake at $\sim 15^{\circ} \mathrm{N}$ corresponds to the sub-Saharan maximum seen in Fig. 1a, which dominates the small land area at that latitude. Three distinct maxima in uptake from May-September are evident in the northern extratropics, due to favourably low diffusivity in NH summer. The largest zonal mean uptake occurs over $10-15^{\circ} \mathrm{S}$ from January to May, when sufficient moisture is available and $r_{\mathrm{SM}}$ is close to unity over most of sub-equatorial South America and Africa. This situation changes dramatically in May, when $r_{\mathrm{SM}}$ falls to $<0.4$ in these areas, and remains low until October.

Figure $6 \mathrm{~b}$ shows the difference between zonally averaged uptake in the present and future climates. To better understand how $\Delta D_{\text {soil }}, \Delta r_{T}$, and $\Delta r_{\mathrm{SM}}$ contribute to the pattern of $\Delta J$, Hovmueller plots of these quantities are shown in Fig. 6c, d, and e. Uptake increases at mid- to high northern latitudes year round, with a maximum of +108 $\mathrm{mgCH}_{4} \mathrm{~m}^{-2} \mathrm{y}^{-1}$ (a $68 \%$ increase over present day values) in June. Inspection of 2-D maps of monthly $\Delta J$ show the largest absolute increases of over $600 \mathrm{mgCH}_{4} \mathrm{~m}^{-2} \mathrm{y}^{-1}$ occur in western and north-central Russia in June, and in western Brazil in September. Comparing Fig. 6a and 6b shows that 
(a)
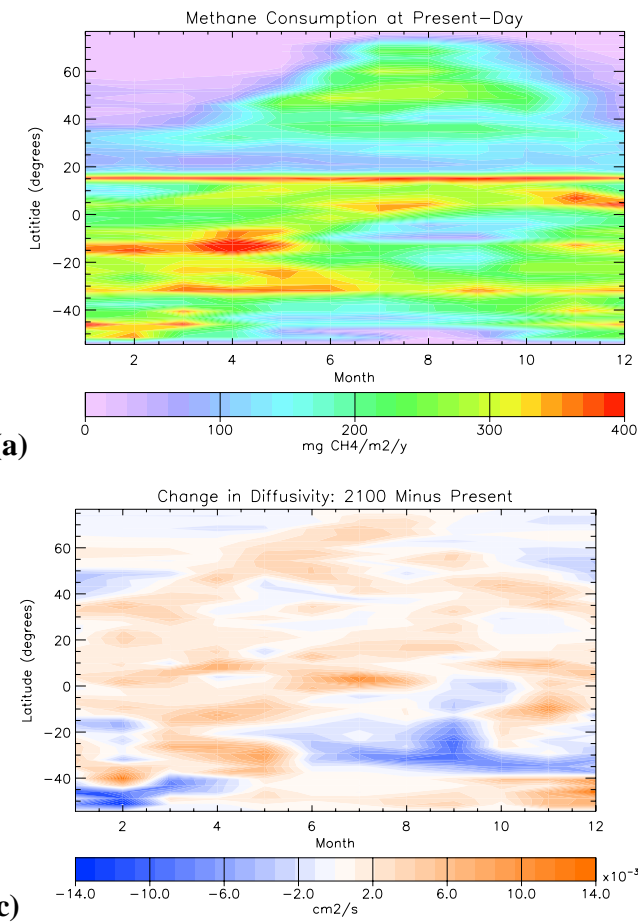

(b)
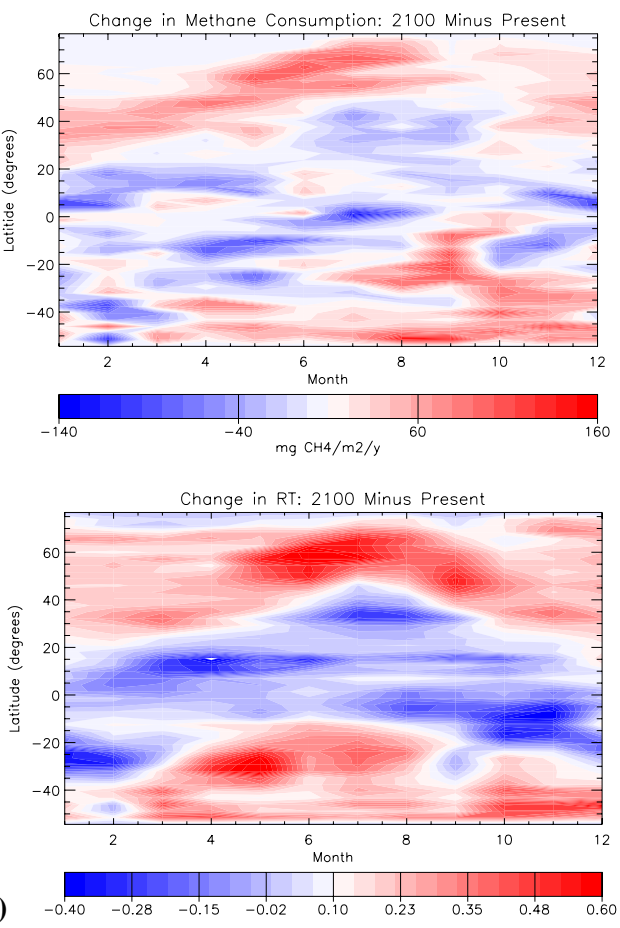

(d)

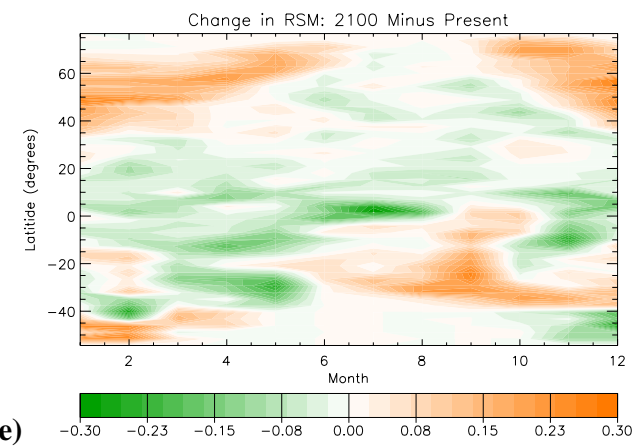

Fig. 6. Hovmueller diagram showing the seasonal cycle of (a) methane uptake in the present-day model climate $\left(\mathrm{mg} \mathrm{CH}_{4} \mathrm{~m}^{-2} \mathrm{y}^{-1}\right)$, and differences between year 2100 and present-day of: (b) methane uptake $\left(\mathrm{mg} \mathrm{CH}_{4} \mathrm{~m}^{-2} \mathrm{y}^{-1}\right)$; (c) diffusivity $\left(\mathrm{cm}^{2} 4 \mathrm{~s}^{-1}\right)$; (d) $r_{T}$ (dimensionless); and (e) $r_{\mathrm{SM}}$ (dimensionless).

the largest increases in uptake generally occur at or near uptake minima in the present day state. For example, in the present day climate at $50^{\circ} \mathrm{N}, \mathrm{CH}_{4}$ consumption essentially ceases between January and March each year as $T_{\text {soil }}$ falls below freezing. In the future climate, however, $J$ exceeds 40 $\mathrm{mgCH}_{4} \mathrm{~m}^{-2} \mathrm{y}^{-1}$ in all months at this latitude. The largest relative change in $\mathrm{NH}$ methane uptake occurs from October to April at $70-80^{\circ} \mathrm{N}$, when consumption can increase by a factor of ten or more over the small present day values (Fig. 6a).

The results of Table 1, Figs. 5 and 6 imply that the uptake enhancement at high northern latitudes is due to the joint increase of $r_{T}$ and $D_{\text {soil }}$ into the future period. Specifically, the poleward extension of warmer temperatures is chiefly responsible for the year-round increase in methane flux in 2100 , while the summer peak in $\Delta J$ can be ascribed to a corresponding increase in $D_{\text {soil }}$, the result of increased evaporation in summer. Although $r_{\mathrm{SM}}$ also displays a large increase north of $40^{\circ} \mathrm{N}$ from fall through spring (Fig. 6e), this is largely countered by decreases in $D_{\text {soil }}$ due to higher snowmelt, leading to a weak correlation between $\Delta r_{\mathrm{SM}}$ and $\Delta J$ at these more northerly latitudes (Table 1).

In the SH, a notable increase in $J$ occurs between midJuly and September (Fig. 6b). From mid-September until the end of the year, large increases in uptake are seen in all SH land areas poleward of $25^{\circ} \mathrm{S}$. In southern Chile, as in the $\mathrm{NH}$, uptake enhancement is due to the poleward shift of the soil temperature isotherms - but this is virtually the only SH location where it occurs. As can be seen from Fig. $6 \mathrm{~b}$ to e, the $\mathrm{CH}_{4}$ flux increase in SH spring-summer is much better correlated with increases in $r_{\mathrm{SM}}$ than in either $r_{T}$ or $D_{\text {soil }}$; indeed, 
Table 2. Annual mean values at present-day and change (year 2100 minus present) in methane consumption by aggregated Holdridge life zone $(\mathrm{AHLZ})^{\mathrm{a}}$.

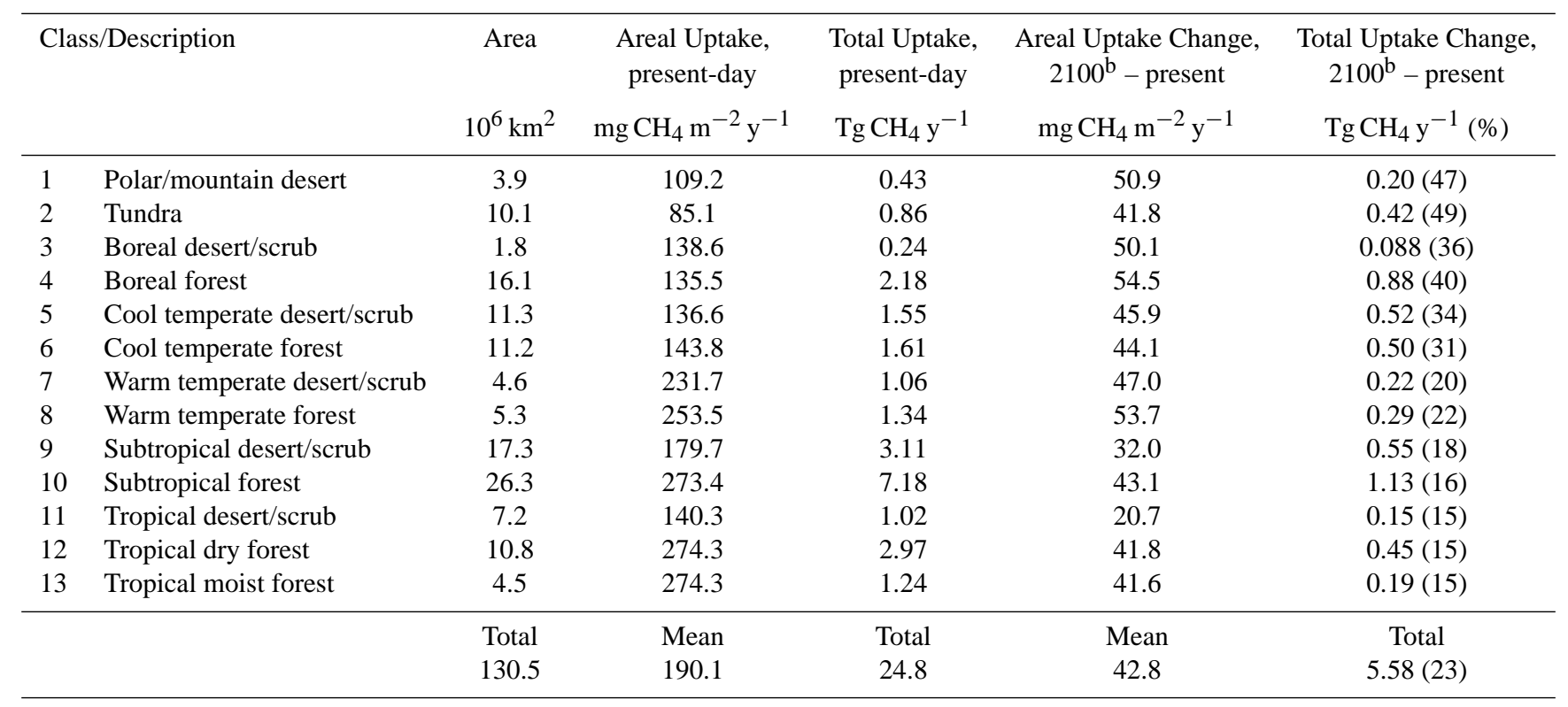

a Although not a AHLZ class, large contiguous areas of high crop coverage ( $>50 \%$ ) overlap with AHLZ classes 4, 5, 6, and 8 in central North America and central western Asia, and AHLZ classes 5, 9, 10 and 12 in India. Similarly, large grassland areas (coverage > 50\%) are found within AHLZ classes 4, 5, 8, 9 and 10 in North and South America, classes 2, 3, 4 and 5 in central and eastern Asia, and classes 8, 9, 11 and 12 in Africa and Australia. Data on global crop and grassland coverage was taken from the $5^{\prime}$ resolution HYDE dataset for 1990 (History Database of the Global Environment, 2009).

b With concentration effect included (Sect. 5.1).

$D_{\text {soil }}$ shows a strong anti-correlation in this instance. The tendency for $J$ to decrease with decreasing $r_{\mathrm{SM}}$ is also seen quite clearly in Figs. $6 \mathrm{~b}$ and e. This emphasizes once again the prevailing influence of $r_{\mathrm{SM}}$ in the $\mathrm{SH}$, paralleling that of $r_{T}$ in the NH. In general, the pattern of $\Delta D_{\text {soil }}$, which largely complements that of $\Delta r_{\mathrm{SM}}$ (as expected, since increasing soil moisture leads to decreased air-filled porosity), appears to be of secondary importance. One exception is from MaySeptember at $30-40^{\circ} \mathrm{S}$, where a persistent decrease in $D_{\text {soil }}$ causes $\Delta J<0$, even in the presence of increased $r_{\mathrm{SM}}$. But aside from this, $D_{\text {soil }}$ has a discernable effect on $\Delta J$ only when reinforced by an associated change in $r_{T}$. An example of this occurs in January-February at $50^{\circ} \mathrm{S}$ (southern Chile, where the largest $\Delta D_{\text {soil }}$ occurs globally), where a large decrease in $D_{\text {soil }}$ coupled with a slight decrease in $r_{T}$ leads to a local minimum in $\Delta J$.

\subsection{Change in uptake by ecosystem type}

Analysis of the geographical distribution of methane consumption under meteorological forcing in Paper I revealed that subtropical and dry tropical ecosystems account for over half of the present-day uptake. I now examine how the distribution of uptake over ecosystem type (as represented by aggregated Holdridge life zone; see Paper I) is altered by climate change, assuming a static distribution of ecosystem types. While the latter supposition is likely invalid under strong climate forcing, this approach does permit a straightforward accounting of changes to uptake in specific geographical regions.

Table 2 shows that, with the exception of tropical and subtropical deserts, where $\Delta J$ is considerably lower than the values seen elsewhere, the change in areal uptake lies in the narrow range of $42-55 \mathrm{mgCH}_{4} \mathrm{~m}^{-2} \mathrm{y}^{-1}$ across ecosystem types. However, the relative increase in uptake is up to three times larger in polar, boreal and cool temperate regions than in the subtropics and tropics. This is consistent with the results of Sect. 5.1 and Fig. $3 \mathrm{~b}$ in particular, which shows large relative increases in flux only in the NH extratropics. Subtropical forests, which had the largest areal and total $\mathrm{CH}_{4}$ consumption in Paper I, also undergo the largest total increase in future. But the largest areal increase occurs in boreal forest ecosystems, resulting in a total uptake change that is almost as large as for subtropical forests.

\subsection{Further simulations}

Using the same model configuration, I also investigated the behaviour of the soil methane sink under differing surface GHG concentration forcings, specifically for preindustrial and other future concentration scenarios. Table 3 compares the global mean uptake results for the A1B scenario in 2100 with the $\mathrm{A} 2$ and $\mathrm{B} 1$ scenarios, and also with a simulation using preindustrial (circa 1850) GHG concentrations. Recall 
Table 3. Annual, global mean $\mathrm{CH}_{4}$ uptake and change (difference from present day) in various quantities under specified forcing scenarios.

\begin{tabular}{|c|c|c|c|c|c|}
\hline Scenario, epoch & $\begin{array}{c}J^{\mathrm{a}} \\
\mathrm{Tg} \mathrm{CH}_{4} \mathrm{y}^{-1}\end{array}$ & $\begin{array}{c}\Delta J^{\mathrm{b}} \\
\%\end{array}$ & $\begin{array}{c}\Delta D_{\text {soil }} \\
\%\end{array}$ & $\begin{array}{c}\Delta r_{T} \\
\%\end{array}$ & $\begin{array}{c}\Delta r_{\mathrm{SM}} \\
\%\end{array}$ \\
\hline Present, $1994^{\mathrm{c}}$ & 24.8 & $\ldots$ & $\ldots$ & $\ldots$ & $\ldots$ \\
\hline Pre-ind., $1850^{\mathrm{d}}$ & 10.2 & -4.8 & -2.8 & -6.6 & -1.5 \\
\hline $\mathrm{B} 1,2100^{\mathrm{e}}$ & 23.7 & +4.4 & +2.0 & +3.7 & +1.9 \\
\hline$A 1 B, 2100^{f}$ & 30.4 & +7.5 & $+\mathbf{5 . 1}$ & +6.4 & $+\mathbf{3 . 0}$ \\
\hline $\mathrm{A} 2,2100^{\mathrm{g}}$ & 56.6 & +11.3 & +10.0 & +7.5 & +4.4 \\
\hline
\end{tabular}

\footnotetext{
${ }^{a}$ With concentration effect included (Sect. 5.1).

$\mathrm{b}$ With concentration effect removed (Sect. 5.1).

${ }^{c}$ Using concentrations $\mathrm{CH}_{4}=1720$ ppbv, $\mathrm{CO}_{2}=358$ ppmv, $\mathrm{N}_{2} \mathrm{O}=311$ ppbv, CFC $-11=266$ pptv, CFC $-12=522$ pptv.

${ }^{\mathrm{d}}$ Using historical (circa 1850) concentrations of $\mathrm{CH}_{4}=792 \mathrm{ppbv}, \mathrm{CO}_{2}=288 \mathrm{ppmv}, \mathrm{N}_{2} \mathrm{O}=275.5 \mathrm{ppbv}, \mathrm{CFC}-11=\mathrm{CFC}-12=0$.

e Using concentrations $\mathrm{CH}_{4}=1569$ ppbv, $\mathrm{CO}_{2}=540$ ppmv, $\mathrm{N}_{2} \mathrm{O}=375$ ppv, CFC-11=45 pptv, CFC $-12=222$ pptv.

${ }^{\mathrm{f}}$ Scenario discussed in detail in Sect. 5 and 6, using concentrations $\mathrm{CH}_{4}=1974$ ppbv, $\mathrm{CO}_{2}=717$ ppmv, $\mathrm{N}_{2} \mathrm{O}=372 \mathrm{ppbv}$, CFC-11=45 pptv, CFC-12=222 pptv.

g Using concentrations $\mathrm{CH}_{4}=3731$ ppbv, $\mathrm{CO}_{2}=836$ ppmv, $\mathrm{N}_{2} \mathrm{O}=447$ ppbv, CFC-11=45 pptv, CFC-12=222 pptv.
}

that most of the variation in $J$ between scenarios (column 2 of Table 3) arises from differences in $\mathrm{CH}_{4}$ concentration at various epochs. For example, the preindustrial and A2 scenario $\mathrm{CH}_{4}$ concentrations differ by a factor of 4.7 , while the ratio of their respective $J$ values is 5.5. To gauge the effect of climate change alone on $\mathrm{CH}_{4}$ consumption, column 3 of Table 3 shows $\Delta J$ with the concentration effect removed. The global mean uptake change based on the future scenarios ranges from +4 to $11 \%$. As might be expected, the global mean $\Delta J$ scales roughly with the corresponding temperature change, with $\Delta J<0$ in the preindustrial simulation. The preindustrial uptake is $5 \%$ below the present day value. The most scenario-dependent of the primary factors appears to be $\Delta r_{T}$, except in the A2 scenario, where the relative increase in $\Delta D_{\text {soil }}$ is larger, possibly due to more evaporation at high latitudes than in the other scenarios.

\section{Discussion and conclusions}

R99 approximated the effect of climate change upon methane uptake in their offline model by calculating the total $\mathrm{CH}_{4}$ uptake under a globally uniform $T_{\text {soil }}$ increase. When the authors fixed the model soil moisture at present-day values, they found that following a small increase from $\Delta T_{\text {soil }}=0$ to $1.5^{\circ}, J$ decreased at higher $\Delta T_{\text {soil }}$ due to the frequent exceedence of the $r_{T}$ maximum in the tropics (Sect. 5.1.1). This led R99 to conclude that the effect of temperature increase alone (of magnitude $z 1.5^{\circ}$ ) is to decrease total methane uptake. In a second calculation, R99 allowed the soil moisture (but not precipitation) to vary according to their hydrological model response to $\Delta T_{\text {soil }}$. In this case, decreasing soil moisture from rising temperatures and higher evaporation rates increased diffusivity overall, causing $J$ to increase by $9 \%$ globally at $\Delta T_{\text {soil }}=5^{\circ} \mathrm{C}$. The role of $r_{\mathrm{SM}}$ in this experiment is not clear; presuming it was allowed to vary with soil moisture, this means that $J$ would have increased further had $r_{\mathrm{SM}}=1$. However, the neglect of precipitation changes in the second experiment probably overestimated $D_{\text {soil }}$ in the extratropics, likely leading to an overestimated $\Delta J$ there (e.g., see Fig. 5).

In the present study, a more complex interplay of the influence of temperature, soil moisture, and moisture stress on methane uptake has emerged. The model develops a nonuniform pattern of both soil temperature and precipitation change from present-day to 2100 , which results in the complex pattern of $\Delta J$ displayed in Fig. 3. Remarkably, however, the global mean value of $\Delta J=+7.5 \%$ agrees closely with R99's second estimate, especially when the lower global mean $\Delta T_{\text {soil }}=3.5^{\circ} \mathrm{C}$ is considered (the corresponding $\mathrm{R} 99$ value at the same $\Delta T_{\text {soil }}$ is $+7.6 \%$ ). But as Fig. 5 shows, R99's assessment of the role of the sensitivity of $J$ to separate changes in $T_{\text {soil }}$ and $D_{\text {soil }}$ is too simplistic.

In our experiments, the increase of $T_{\text {soil }}$ in the tropics does lead to lower $r_{T}$, and thus decreased $J$ over the range $10^{\circ} \mathrm{S}$ $15^{\circ} \mathrm{N}$, but the change is much smaller than the increases seen at higher latitudes (Fig. 5). The small tropical $\Delta r_{T}$ is likely due to the combined effect of lower than average $\Delta T_{\text {soil }} \simeq 3.0^{\circ} \mathrm{C}$ and decreasing precipitation over land at these latitudes. By neglecting $\Delta D_{\text {soil }}$ and $\Delta r_{\mathrm{SM}}$ in Eq. (3), one can approximate the effect of fixed soil moisture on our results. The resulting global mean relative change in $J$ due to $\Delta r_{T}$ alone is $\sim+2 \%$, or about one-quarter of the total change in $J$, not a decrease in $J$ as predicted by R99.

It is also apparent from our results that, even when diffusivity decreases, $J$ can increase due to increased soil temperature and favourable $r_{\mathrm{SM}}$ in the extratropics (e.g., over eastern Asia in Fig. 4). The annual mean diffusivity increases over $\sim 60 \%$ of land-only grid cells north of $45^{\circ} \mathrm{N}$, while $J$ increases over $98 \%$ of the cells and $T_{\text {soil }}$ increases globally. 
As discussed in Sect. 5.1.4, diffusivity is strongly controlled by factors other than temperature, including precipitation, porosity, and snow cover (Sect. 5.1 and Fig. $4 \mathrm{~d}$ and e).

Interestingly, Table 3 shows that the global mean change in the soil moisture stress factor $r_{\mathrm{SM}}$ is small and of positive sign in all scenarios and, moreover, is relatively insensitive to scenario. This is somewhat surprising, given that $r_{\mathrm{SM}}$ was found to be the chief factor limiting uptake in Paper I. This outcome is the result of offsetting changes north and south of $\sim 45^{\circ} \mathrm{N}$ in all of the simulations (Fig. $4 \mathrm{~b}$; note that land north of $45^{\circ} \mathrm{N}$ comprises $36 \%$ of the global land area, omitting Greenland and Antarctica). Many qualitative predictions of soil water availability in a warmer climate seem to have overlooked the possibility of increasing $r_{\mathrm{SM}}$ at high northern latitudes due to increased snowmelt and/or snowfall, as seen in the simulations presented here. Even in the A2 scenario, where the annual mean surface air temperature change north of $45^{\circ} \mathrm{N}$ is $+7.1^{\circ} \mathrm{C}$ by $2100, r_{\mathrm{SM}}$ still increases by $4.4 \%$.

While this work is a first attempt at calculating the change in methane uptake at the global scale, the influence of several factors has been neglected. Among these are: 1) anthropogenic land-use change, which leads to changes in the cultivation fraction $r_{N}$ with time (Ojima et al., 1993); 2) the evolution of natural wetlands, which leads to a changing pattern of $r_{W} ; 3$ ) changes in the spatial distribution of ecosystem types, which requires a dynamic vegetation model; and 4) the effect of changes in soil type and physical characteristics at centennial time scales, which a prescribed global soil texture dataset, such as that used here, cannot capture.

However, the most evident limitation of the present approach is its neglect of methanogenesis, as the method applies only to unsaturated surface soils where aerobic processes dominate over anaerobic ones. Although wetlands cover only around 5\% of the Earth's ice-free land surface (Prigent et al., 2009), they are responsible for a disproportionate fraction of global methane emissions (25-40\% of the annual total, according to a range of estimates; Denman et al., 2007), and thus need to be included in any dynamic model of the methane budget. A more complex soil thermal and hydrological scheme than that used here, including a dynamic water table, is needed to capture the behaviour of key biogeochemical feedbacks, such as methane release to the atmosphere by northern wetlands and carbon sequestration in peatlands under future warming. Progress is now being made in this direction by other researchers (Zhuang et al., 2004; Wania et al., 2009).

Another shortcoming of the present calculations, which is readily remedied, is the adoption of a single uniform value for the $\mathrm{CH}_{4}$ surface concentration. Current observations indicate a significant north-south gradient in surface $\mathrm{CH}_{4}$, of order $140 \mathrm{ppbv}$ or $8 \%$ of the global mean value (Climate Monitoring and Diagnostics Laboratory, 2001). Since both $\mathrm{CH}_{4}$ concentrations and land area are largest in the $\mathrm{NH}$, using a more realistic surface concentration distribution should lead to an even larger north/south imbalance in the methane sink than already seen (approximately 60/40, according to Paper I), and a slightly larger global uptake. Furthermore, the parameterization of methane consumption utilized in this paper can be combined with a simplified atmospheric $\mathrm{CH}_{4}$ chemistry scheme, already tested in AGCM3 (Curry et al., 2006), to enable completely prognostic methane sinks in a coupled GCM. For a prescribed surface $\mathrm{CH}_{4}$ concentration field, running the model to equilibrium would then determine the relative contributions of the atmosphere and soil to the total $\mathrm{CH}_{4}$ sink. Alternatively, if instead the surface source distribution of $\mathrm{CH}_{4}$ emissions ( $\sim 60 \%$ of which are anthropogenic) were prescribed, this would allow the determination of the 3-D methane concentration field. The latter approach would then be suitable for use in transient climate simulations, e.g., along the lines of the $\mathrm{C}^{4} \mathrm{MIP}$-type experiments conducted with carbon cycle GCMs (Friedlingstein et al., 2006).

In the meantime, the estimates of the present paper give some notion of what to expect for the soil sink portion of the methane budget under the anticipated GHG increases in future decades. In particular, this work has clearly identified the relative roles of the key contributing factors to soil methane consumption in the majority of climatic zones and biomes.

Acknowledgements. I would like to thank Slava Kharin for advice on the correlation analysis, and Vivek Arora, Rita Wania, and an anonymous referee for helpful comments on the manuscript. The author was supported for a portion of this work by the Canadian Foundation for Climate and Atmospheric Sciences, as part of the Canadian Global Coupled Carbon Climate Model $\left(\mathrm{CGC}^{3} \mathrm{M}\right)$ research network.

Edited by: J. Kesselmeier

\section{References}

Climate Monitoring and Diagnostics Laboratory: GLOBALVIEW$\mathrm{CH}_{4}$ : Cooperative Atmospheric Data Integration Project - Methane, CD-ROM, NOAA, Boulder, CO, USA, also available via anonymous ftp at ftp.cmdl.noaa.gov, path ccg/ch4/GLOBALVIEW, 2001.

Curry, C. L.: Modelling the soil consumption of atmospheric methane at the global scale, Global Biogeochem. Cy., 21, GB4012, doi:10.1029/2006GB002818, 2007.

Curry, C. L., McFarlane, N. A., and Scinocca, J. F.: Relaxing the well-mixed greenhouse gas approximation in climate simulations: Consequences for stratospheric climate, J. Geophys. Res., 111, D08104, doi:10.1029/2005JD006670, 2006.

Denman, K. L., Brasseur, G., Chidthaisong, A., Ciais, P., Cox, P. M., Dickinson, R., Hauglustaine, D., Heinze, C., Holland, E., Jacob, D., Lohmann, U., Ramachandran, S., da Silva Dias, P., Wofsy, S. C., and Zhang, X.: Couplings Between Changes in the Climate System and Biogeochemistry, in: Climate Change 2007: The Physical Science Basis. Contribution of Working Group I to the Fourth Assessment Report of the Intergovernmental Panel on Climate Change, edited by: Solomon, S., Qin, D., Manning, M., 
Chen, Z., Marquis, M., Averyt, K. B., Tignor, M., and Miller, H. L., 499-587, Cambridge Univ. Press, Cambridge and New York, 2007.

Dirmeyer, P. and Tan, L.: A multi-decadal global land-surface data set of state variables and fluxes, Centre for OceanLand-Atmosphere Studies, Cent. for Ocean-Land-Atmos. Stud., Calverton, MD, USA, COLA Tech. Rep. 102, also available at http://www.iges.org/pubs/tech.html, 2001.

Dutaur, L. and Verchot, L. V.: A Global Inventory of the Soil $\mathrm{CH}_{4}$ Sink, Global Biogeochem. Cy., 21, GB4012, doi:10.1029/ 2006GB002818, 2007.

Friedlingstein, P., Cox, P., Betts, R., Bopp, L., von Bloh, W., Brovkin, V., Cadule, P., Doney, S., Eby, M., Fung, I., Bala, G., John, J., Jones, C., Joos, F., Kato, T., Kawamiya, M., Knorr, W., Lindsay, K., Matthews, H. D., Raddatz, T., Rayner, P., Reick, C., Roeckner, E., Schnitzler, K.-G., Schnur, R., Strassmann, K., Weaver, A. J., Yoshikawa, C., and Zeng, N.: Climate-carbon cycle feedback analysis: Results from the $\mathrm{C}^{4} \mathrm{MIP}$ model intercomparison, J. Climate, 19, 3337-3353, 2006.

Hanson, R. S. and Hanson, T. E.: Methanotrophic bacteria, Microbiol. Rev., 60, 439-471, 1996.

Hegerl, G. C., Zwiers, F. W., Braconnot, P., Gillett, N. P., Luo, Y., Orsini, J. A. M., Nicholls, N., Penner, J. E., and Stott, P. A.: Understanding and Attributing Climate Change, in: Climate Change 2007: The Physical Science Basis, Contribution of Working Group I to the Fourth Assessment Report of the Intergovernmental Panel on Climate Change, edited by: Solomon, S., Qin, D., Manning, M., Chen, Z., Marquis, M., Averyt, K. B., Tignor, M., and Miller, H. L., Cambridge Univ. Press, Cambridge and New York, 663-745, 2007.

History Database of the Global Environment (HYDE), Netherlands Environmental Assessment Agency, Bilthoven, The Netherlands, Data available at http://www.mnp.nl/en/themasites/hyde/ downloaddata/index.html, 2009.

Horz, H. P., Rich, V., Avrahami, S., and Bohannan, B. J. M.: Methane-oxidizing bacteria in a California upland grassland soil: Diversity and response to simulated global change, Appl. Environ. Microb., 71, 2642-2652, doi:10.1128/AEM.71. 5.2642-2652.2005, 2005.

Knief, C., Lipski, A., and Dunfield, P.: Diversity and activity of methanotrophic bacteria in different upland soils, Appl. Environ. Microb., 69, 6703-6714, doi:10.1128/AEM.69.11.6703-6714. 2003, 2003.

McFarlane, N. A., Boer, G. J., Blanchet, J.-P., and Lazare, M.: The Canadian Climate Centre second-generation general circulation model and its equilibrium climate, J. Climate, 5, 1013-1044, 1992.
McFarlane, N. A., Scinocca, J. F., Lazare, M., Harvey, R., Verseghy, D., and Li, J.: The CCCma third generation atmospheric general circulation model, CCCma Internal Rep., 40 pp., available at http://www.cccma.ec.gc.ca/models/gcm3.shtml, 2005.

Ojima, D. S., Valentine, D. W., Mosier, A. R., Parton, W. J., and Schimel, D. S.: Effect of land use change on methane oxidation in temperate forest and grassland soils, Chemosphere, 26, 675685, 1993.

Prigent, C., Papa, F., Aires, F., Rossow, W. B., and Matthews, E.: Global inundation dynamics inferred from multiple satellite observations, 1993-2000, J. Geophys. Res., 112, D12107, doi: 10.1029/2006JD007847, 2009.

Ridgwell, A., Marshall, S. J., and Gregson, K.: Consumption of atmospheric methane by soils: a process-based model, Global Biogeochem.Cy., 13, 59-70, 1999.

Roslev, P., Iversen, N., and Henriksen, K.: Oxidation and assimilation of atmospheric methane by soil methane oxidizers, Appl. Environ. Microb., 63, 874-880, 1997.

Schnell, S. and King, G. M.: Responses of methanotrophic activity in soils and cultures to water stress, Appl. Environ. Microb., 62, 3203-3209, 1996.

Torn, M. S. and Harte, J.: Methane consumption by montane soils: implications for positive and negative feedback with climatic change, Biogeochemistry, 32, 53-67, 1996.

Verseghy, D. L.: CLASS - A Canadian Land Surface Scheme for GCMs. I. Soil model, Int. J. Climatol., 11, 111-133, 1991.

Verseghy, D. L.: Local climates simulated by two generations of Canadian GCM land surface schemes, Atmos. Ocean, 34, 435456, 1996.

von Fischer, J. C., Butters, G., Duchateau, P. C., Thelwell, R. J., and Siller, R.: In situ measures of methanotroph activity in upland soils: A reaction-diffusion model and field observation of water stress, J. Geophys. Res., 114, G01015, doi:10.1029/ 2008JG000731, 2009.

Wania, R., Ross, I., and Prentice, I. C.: Integrating peatlands and permafrost into a dynamic global vegetation model: I. Evaluation and sensitivity of physical land surface processes, Global Biogeochem. Cy., doi:10.1029/2008GB003412, in press, 2009.

Zhuang, Q., Melillo, J. M., Kicklighter, D. W., Prinn, R. G., McGuire, A. D., Steudler, P. A., Felzer, B. S., and Hu, S.: Methane fluxes between terrestrial ecosystems and the atmosphere at northern high latitudes during the past century: A retrospective analysis with a process-based biogeochemistry model, Global Biogeochem. Cy., 18, GB3010, doi:10.1029/ 2004GB002239, 2004.

Zobler, L.: A world soil file for climate modelling, NASA Tech. Mem. 87802, NASA, 1986. 